\title{
Effects of Two Yeast based Direct Fed Microbials on Performance
}

\section{of High Producing Dairy Cows}

\author{
H.C.vdW. Leicester ${ }^{a, b}$, P.H. Robinson ${ }^{b}$, L.J. Erasmus ${ }^{a}$ \\ ${ }^{a}$ Department of Animal and Wildife Sciences, University of Pretoria, South Africa \\ ${ }^{b}$ Department of Animal Science, University of California, Davis, CA 95616, USA
}

${ }^{*}$ Corresponding author. Tel.: 1-530-754-7565

E-mail address: phrobinson@ucdavis.edu (P.H. Robinson)

\section{Highlights}

- A yeast culture (XPC) or yeast/microbial culture (YST) were added to a Control (C)

- Milk yield was higher with YST, but not XPC, and NE output was higher $v s \mathrm{C}$ for both

- There were no impacts of either YST or XPC on measures of rumen fermentation

- Lower apparent digestion of OM and CP for YST vs C and mainly higher plasma AA

- A post-ruminal YST effect improved gut health causing higher absorption efficiency

\begin{abstract}
Our aim was to determine effects of two S. cerevisiae yeast based direct fed microbial (DFM) feed additives on the productive response of high producing early lactation dairy cows. The study consisted of three high producing Holstein cow pens $( \pm 315$ cows/pen) in a $3 \times 3$ Latin square design experiment with 3 periods of $28 \mathrm{~d}$ each. The 3 treatments were: 1 ) Basal total mixed ration (Control), 2) Control supplemented with 'XPC' yeast culture at 14 g/cow/d and, 3) Control supplemented with 'Yeasture (YST)' DFM at $10 \mathrm{~g} / \mathrm{cow} / \mathrm{d}$. Milk (P $=0.01)$, milk true protein $(P=0.01)$, lactose $(P=0.01)$ and energy $(P=0.02)$ outputs were higher for YST cows, and there was a tendency for milk fat $(P=0.07)$ to increase compared to Control cows. In contrast, milk and component yields were not impacted by feeding XPC.
\end{abstract}


Total net energy (NE) output was higher for both DFM treatments versus Control (YST $(P<$ $0.01)$ and XPC $(P=0.01))$, but neither treatment impacted the NE level of the diets. Total tract apparent digestibility of organic matter $(\mathrm{OM})$ and crude protein $(\mathrm{CP})$ tended to be lower $(P=0.08$ and 0.05$)$ than Control for the XPC treatment, while total tract apparent digestibility of OM and CP for YST cows was lower $(P=0.02$ and $<0.01$ respectively) than Control. Total tract apparent digestibility of ash-free neutral detergent fibre (aNDFom) and starch were not affected by treatment, and there was no effect of either DFM treatment on microbial CP (MCP) flow from the rumen. Total plasma essential amino acid (EAA) concentrations tended to be higher $(P=0.07)$ with YST, which was mainly driven by increases in threonine $(P=0.03)$, tryptophan $(P=0.02)$, valine $(P=0.08)$ and histidine $(P=$ 0.06). Although total plasma non-essential amino acids (NEAA) did not differ with YST feeding, there was an increase in concentrations of glycine $(P=0.04)$, asparagine $(P=0.03)$, tyrosine $(P=0.05)$, serine $(P=0.07)$, proline $(P=0.06)$ and taurine $(P=0.07)$. In contrast, XPC had no impact on plasma concentrations of any AA. Overall, MCP flow and whole tract aNDFom data suggest no substantive impact of either yeast additive on rumen fermentation, but whole tract digestibility of OM and plasma AA concentrations suggest a post-ruminal effect of YST wherein gut health improved thereby leading to increased efficiency of nutrient absorption.

Keywords: DFM, XPC, Yeasture, allantoin

Abbreviations: AA, Amino acids; ADF, Acid detergent fibre; ADICP, AD insoluble CP; AL, Allantoin; aNDFom, ash free eutral detergent fibre assayed with alpha amylase; BCS, Body condition score; CP, Crude Protein; DDGS, Dried distillers grains with solubles; DFM, Direct fed microbial; DIM, Days in milk; DM, Dry matter; EAA, Essential AA; EE, Ether 
extract; GI, Gastrointestinal; MCP, Microbial CP; NEAA, Non-essential AA; NEact, NE activity; $\mathrm{NE}_{\mathrm{L}}, \mathrm{NE}$ lactation; NEm, NE maintenance; $\mathrm{OM}$, organic matter; $\mathrm{PD}$, Purine derivative; SCC, Somatic cell count; SG, Specific gravity; TMR, Total mixed ration; YST, Yeasture.

\section{Introduction}

Although there are several commercial Saccharomyces cerevisiae yeast based products, as well as substantial research completed on supplementing yeast based products to ruminant diets, results are variable (Robinson and Erasmus, 2008). While many claims have been made about the impacts of yeast based products on ruminant animal performance, which include improved feed intake, feed efficiency, rumen fiber fermentation, rumen microbial protein (MCP) synthesis, rumen $\mathrm{pH}$ and digestion, all involve ruminal mechanisms. Indeed rumen fermentation processes play a key role in ruminant nutrition (Van Soest, 1994), and the extent of interactions among microbial populations in the rumen is so complex that many pathways remain unknown (Russell, 2002). Thus ruminant nutritionists and microbiologists have the same objective, which is to increase nutrient utilization in the rumen.

Concerns about use of antibiotics in livestock feeding are well known due to the occurrence of antibiotic resistant bacteria that might represent a risk to human health (Barton, 2000). This concern led to use of ionophores as growth stimulants in food animals being banned in the European Union in January 2006 (Regulation 1831/2002/EC; DiLorenzo, 2010). Thus the search for safe, high quality and efficacious feed additives has led research to focus on 'natural' alternative additives such as direct fed microbial's (DFM) and essential oils (Patra, 2011), and how they can be used to improve efficiency of animal production, whether by improving rumen fermentation, decreasing methane production, reducing nutritional stressors such as acidosis and bloat, improving post rumen gastrointestinal (GI) 
health with the overall objective of increasing the health and productivity of dairy cows. Direct fed microbials are a common dairy feed additive worldwide but, due to variability in animal responses and introduction of new additives, continuing research is needed to demonstrate efficacy.

The objectives were to determine effects of the two $S$. cerevisiae yeast based feed additives on dry matter (DM) intake, whole tract apparent digestibility, rumen fermentation, body condition score (BCS), milk yield and milk composition of lactating Holstein dairy cows in order to determine if it is beneficial to include these additives in their diets

\section{Materials and methods}

\subsection{Study location, duration and experimental design}

The study was completed on a commercial dairy farm near Hanford (CA, USA) and encompassed the 12 wks from 23 January 2014 to 17 April 2014. The experimental period was divided into 3 periods of 4 wks. In every experimental period there was a 3 wk adaption followed by a $4^{\text {th }}$ wk for sample collection. Samples were collected of individual feedstuffs as well as the total mixed ration (TMR), DFM yeasts, urine, blood, milk and feces. The BCS scoring was completed at the start of the study and at the end of each experimental period.

The experimental design was a $3 \times 3$ Latin square with 3 pens, 3 dietary treatments and 3 experimental periods. The treatment TMR differed only in that they contained, or did not contain, one of the DFM yeast based feed additives. Each pen received one of the treatments

during the experiment: 1) Basal TMR (Control); 2) Control supplemented with the Diamond V XPC yeast culture (XPC; 14 g/cow/d). [Diamond V Mills, Cedar Rapids, IA, USA]; 3) Control supplemented with the Yeasture DFM (YST) $(10 \mathrm{~g} / \mathrm{cow} / \mathrm{d})$. [Cenzone Tech, Inc., San Marcos, CA, USA]. Feeding levels were as specified by the manufacturers. 


\subsection{Study cows and pens}

Three pens containing an average of 315 multiparous high producing Holstein cows/pen not yet confirmed in calf and milked three times daily in a double 35 herringbone parlour were used. Cows were moved out of these 'high' pens to a common 'mid' pen after being confirmed pregnant at about 200 days in milk (DIM), and the cows that moved was removed from the study. Pens were similar with a single feed bunk under a roof structure and 297 free stalls with dried manure solids as bedding which was restored weekly, as well as 295 head gates/pen (used to examine cows in morning 'lock up'). There were rubber mats on the walkway between the free stalls and the milking parlour as well as along the feed bunk in the pen in order to minimize foot and leg injuries. Cows were allowed access to an enclosed dirt lot outside of the roofed area daily, except during morning 'lock up'. Clean drinking water was available at all times.

\subsection{Diets}

The TMR's were fed twice daily, but the yeast additives were only included in the first load that was fed in the morning when the cows were being milked. The second feeding, to ensure ad libitum TMR was available all day, and was fed between 11:30 and 12:30 h and did not contain the DFM. The TMR were 'pushed up' every $2 \mathrm{~h}$ during the day to encourage consumption. Diet ingredients are in Table 3.

\subsection{The DFM yeast additives}

Diamond V XPC (XPC) is a recently introduced yeast culture manufactured by Diamond $\mathrm{V}$ Mills containing 15\% CP (minimum), $1.5 \%$ crude fat (minimum), 25\% crude fibre (maximum) and 9\% ash (maximum) as defined by the manufacturer. Product ingredients are Saccharomyces cerevisiae yeast and some of the media on which it is grown, many being processed grain by-products and cane molasses. No viability of yeast cells in XPC is claimed. 
Cenzone Yeasture (YST) is also a new yeast based DFM manufactured by Cenzone Tech, Inc. Yeasture contains 18\% CP (minimum), $1.6 \%$ crude fat (minimum) and 9\% crude fibre (maximum). Viability of the Bacillus subtilis bacteria is a minimum of $1.8 \times 10^{11} \mathrm{CFU}$ and that of the Saccharomyces cerevisiae yeasts is a minimum of $4.5 \times 10^{12}$ cells $/ \mathrm{kg}$ of additive as defined by the manufacturer. Ingredients include Saccharomyces cerevisiae yeast and its cell wall extract, Aspergillus oryzae fermentation extract and Bacillus subtilis fermentation extract.

Yeasts and the yeast cells in yeast cultures are, in general, selected based upon desired efficacy from wild type yeasts, and then produced and concentrated commercially to create proprietary feed additives.

\subsection{Feeding of the yeast additives, feed mixing and feed delivery}

A premix was prepared prior to general TMR mixing consisting of almond hulls, cottonseed (whole upland), mineral premix, canola meal (solvent extracted), mold binder, low quality alfalfa hay, sodium bicarbonate, tallow, DDGS and liquid molasses. The TMR were mixed by loading all feed ingredients into a two screw vertical mixing wagon (Model 1200 T Supreme Feed Processor, Duport TMR Equipment Co., Inc., Visalia, CA, USA) that was on an electronic scale while electronically recording the actual weight of all feeds added by the "TMR tracker" system (Digi-Star LLC, Fort Atkinson, WI, USA). The DFM yeast additives were weighed weekly into bags for daily feeding by pen, and were added to the TMR with the premix.

\subsection{Sampling and data collection}

\subsubsection{Sampling TMR's and feedstuffs}

During each collection period, TMR and feedstuff samples were collected on day 21 and 26. A 3.7 liter plastic bag was used for bulky and wet ingredients such as silages and citrus pulp, while $1 \mathrm{~L}$ plastic bags were used for less bulky ingredients such as canola meal and 
DDGS. Hays and straw was sampled with a golf club style hay probe (Seifert Analytical, Lodi, CA, USA) by taking 8 to 15 probe samples. Other samples were collected with a gloved hand by taking 4 to 8 handfuls of a sample and placing it in a plastic bag.

The TMR samples were collected according to guidelines of Robinson and Meyer (2010), by walking down the bunk line and taking 10 handfuls of the TMR $(\sim 1.1 \mathrm{~kg}$ total) from predetermined locations in the middle of the TMR bunk line directly after it was fed.

\subsubsection{Dry matter intake measurement}

Orts were pushed out of the bunklines each morning prior to fresh TMR feeding. Orts were weighed daily and the amount recorded for each pen in the Digi-Star electronic system.

\subsubsection{Urine collection}

On day 26 of each experimental period a group of 130 to 160 cows/pen were marked with 3M Nexcare waterproof plaster (3M Consumer Health Care, St. Paul, MN, USA) and Super 77 multipurpose adhesive glue (3M Stationary Products Division, St, Paul, MN, USA) by sticking the plaster with the corresponding cow number on the rump of the cow to ensure that cow numbers could be accessed from behind the cows during urine collection. Urine collection occurred on day 27 of each experimental period while cows were in morning 'lockup'. Urine was collected from the free urine flow of rump marked voluntarily urinating cows into $250 \mathrm{ml}$ plastic cups which were placed on ice in a cooler. Urine specific gravity (SG) was measured using a refractometer (Digital Hand-held Refractometer PEN-RI, ATAGO, Tokyo, Japan). Into each urine tube, $1.4 \mathrm{ml}$ of a $0.5 \mathrm{M}$ sulphuric acid was added to prevent microbial degradation of allantoin (Al) and then $7 \mathrm{ml}$ of the urine was added to the tube. The $\mathrm{pH}$ of these samples was measured with a pH meter (Oyster 10 series, EXTECH instruments, Nashua, $\mathrm{NH}$, USA) to ensure that the final $\mathrm{pH}$ was below 3. Urine samples were diluted with $27 \mathrm{ml}$ of deionized water and samples placed in a freezer at $-20^{\circ} \mathrm{C}$. 


\subsubsection{Blood sampling}

Blood collection occurred on day 28 of each experimental period by sampling tail vein blood from a pre-selected group of 16 cows/pen in each period. Cows were selected from those from which urine had been collected in period 1. Blood collection was from the coccygeal vein into a green top evacuated tube containing K2 EDTA (Vacutainer, Becton Dickinson, Franklin Lakes, NJ, USA). After the sample had been collected, blood samples were placed on ice. Blood sub-sampling was completed by centrifuging (Sorvall TM ST 16 R Centrifuge series, Thermo Scientific Inc, Waltham, MA, USA) at $4^{\circ} \mathrm{C}$ at $2100 \times g$ for 15 min. Plasma was transferred into Eppendorf tubes and placed in a freezer at $-20^{\circ} \mathrm{C}$.

\subsubsection{Fecal sampling}

Fecal samples were collected on day 28 of each period from the same pre-selected group of $18 \mathrm{cows} / \mathrm{pen}$ in each period. Cows were selected from those from which urine had been collected in period 1. If spontaneous defecation did not occur, samples were obtained by inserting one hand into the cow's rectum to stimulate defecation. After collection, sample containers for each cow were frozen at $-20^{\circ} \mathrm{C}$. Fecal samples were pooled by combining three groups of 6 cow's fecal samples/pen to create 3 representative fecal samples/pen/period. This was completed to support the assumption that the TMR consumed by these groups of 6 cows/pen groups were representative of all cows in the pen in order to allow diet digestibility calculations. Cow groups were created by sequential cow number.

\subsubsection{Milk sampling}

Dairy Herd Improvement Association in Hanford (CA, USA) collected milk samples on day 28 of each experimental period using WB Auto Samplers (Tru-Test Incorporated, Mineral Wells, TX, USA) to create a composite milk sample for each cow and to record total milk yield. 


\subsubsection{Body condition scoring}

A BCS was assigned to cows at the beginning of the study and at the end of each experimental period in order to calculate change in BCS. The 5 point scoring system was used where 1 indicates severe under condition and 5 indicates severe obesity (Wildman et al., 1982; Ferguson et al., 1994). Body condition scoring was completed to the nearest $1 / 8$ point after the morning milking while the cows were in lockup.

\subsection{Sample preparation and assays}

\subsubsection{Feeds and TMR}

Feed and TMR samples was analyzed for DM, ash, CP, ash free neutral detergent fibre (aNDFom), acid detergent fibre (ADF), lignin(sa), free sugars, acid detergent insoluble CP (ADICP), macro and micro minerals and fat (EE). Three TMR samples/period (1 pooled sample/pen) and 1 pooled sample of each feed/period were analyzed. The DM content of the TMR and wet ingredients (e.g., alfalfa fresh chop, silages, citrus pulp) was calculated by measuring gravimetric weight losses in a forced air oven for $48 \mathrm{~h}$ at $55^{\circ} \mathrm{C}$, leaving it to air equilibrate for $24 \mathrm{~h}$, with analytical DM determined as the gravimetric weight loss by heating the air equilibrated sample to $105^{\circ} \mathrm{C}$ for $3 \mathrm{~h}$ (NFTA, 2001). The final DM value was then calculated by multiplying the air equilibrated DM value by the analytical DM value. All samples were ground to pass a $1 \mathrm{~mm}$ screen on a model 4 Wiley Mill. Total $\mathrm{N}$ and ADIN were determined by the Leco method with a $\mathrm{N}$ gas analyzer using an induction furnace to ignite samples to $900^{\circ} \mathrm{C}$ and a thermal conductivity detector to determine the $\mathrm{N}$ content (\#942.05, AOAC, 2005). The $\mathrm{CP}$ was calculated from $\mathrm{N}$ as $\mathrm{N} \times 6.25$. Lignin(sa) was determined by the reflux method using sulfuric acid and heat to dissolve solubles, leaving a residue of lignin(sa). The ADF was determined gravimetrically as the residue remaining after AD extraction (\#973.18, AOAC, 1997). The NDF was determined by the reflux method using sodium sulfite and heat (Van Soest et al., 1991). Heat stable amylase was added to all 
samples and NDF is reported ash free (e.g., aNDFom). Total ash determination was based on gravimetric loss by heating samples to $550^{\circ} \mathrm{C}$ for $8 \mathrm{~h}$. Soluble carbohydrates were determined by high-performance liquid chromatography using a Phenomenex Luna NH2 $(250 \mathrm{~mm} \times 4.6$ mm) HPLC column at a flow rate of $2.75 \mathrm{ml} / \mathrm{min}$, acetonitrile: water (78:22) (Johansen et al., 1996). Soluble N was determined by the borate phosphate buffer procedure (Krishnamoorthy et al., 1982). Ether extract was quantified using a standard Soxhlet extraction during which fat was dissolved in ethyl ether and residues determined gravimetrically after drying (\#2003.05, AOAC, 2006).

Most minerals (i.e., $\mathrm{P}, \mathrm{S}, \mathrm{Ca}, \mathrm{Mg}, \mathrm{Na}, \mathrm{Zn}, \mathrm{Mn}, \mathrm{Fe}, \mathrm{Cu}, \mathrm{Co}$, Mo) were determined using a nitric acid/hydrogen peroxide microwave digestion/dissolution of samples and quantitative determination by atomic absorption spectrometry (AAS) and inductively coupled plasma by atomic emission spectrometry (Meyer and Keliher, 1992). Total K was determined by atomic emission spectrometry and $\mathrm{Cl}$ by chloridometer after both minerals were extracted by $20 \mathrm{~g} / \mathrm{l}$ acetic acid (Johnson and Ulrich, 1959). Total Se was extracted by nitric/perchloric acid digestion/dissolution and determined by vapor generation using inductively coupled plasma atomic emission spectroscopy (Tracy and Moeller, 1990).

\subsubsection{In vitro gas production}

In vitro gas production used the method described by Blümmel and Ørskov (1993) with calibrated $100 \mathrm{ml}$ syringes of $31 \mathrm{~mm}$ internal diameter (Model Fortuna, Häberle Labortechnik, Lonsee - Ettlenschieb, Germany). Each sample of $200 \mathrm{mg}$ was incubated in 30 $\mathrm{ml}$ buffered rumen liquor in a water bath at $39^{\circ} \mathrm{C}$. Rumen fluid was collected from 2 dry cows fed an all hay diet, and rumen liquor was filtered through 3 layers of cheesecloth. Gas recordings were at $0,4,24,30$ and $48 \mathrm{~h}$ where the $4 \mathrm{~h}$ reading is an indicator of the rapidly fermentable fraction of the ration (Groot et al., 1996), the $24 \mathrm{~h}$ value is indicative of the metabolizable energy (ME) value of the diet at maintenance (Menke and Steingass, 1988), 
the $30 \mathrm{~h}$ value is indicative of the NE available to high producing cows (Robinson et al., 2004), and the $48 \mathrm{~h}$ cumulative gas production is used as an indication of the diet's practical extent of in vitro digestibility (Robinson et al., 2004). A known reference alfalfa hay was used as the internal standard with a $200 \mathrm{mg}$ sample weighed to duplicate syringes. A mixture containing $472.5 \mathrm{ml}$ distilled water, $236.25 \mathrm{ml}$ buffer solution, $236.25 \mathrm{ml}$ main element solution, $0.1185 \mathrm{ml}$ trace element solution and $1.20 \mathrm{ml}$ resazurin solution per liter was prepared in an Erlenmeyer flask. After warming to $39^{\circ} \mathrm{C}$, and continuous flushing with $\mathrm{CO}_{2}$, a reduction solution consisting of $45.0 \mathrm{ml}$ distilled water, $1.875 \mathrm{ml} 1 \mathrm{~N} \mathrm{NaOH}$, and $296.25 \mathrm{mg}$ $\mathrm{Na}_{2} \mathrm{~S} \bullet 9 \mathrm{H}_{2} \mathrm{O}$ was added. The ratio of rumen liquor to buffer was 1:2. Syringes were shaken gently before each measurement. Total gas values were corrected for blank incubations, but not for the alfalfa hay standard as its values were within range for all in vitro runs.

All 19 samples (i.e., 3 TMR/period, 1 control TMR with XPC added/period, 1 control TMR with YST added/period as well as 2 standards and 2 blanks) were assayed in one run. The control TMR with directly added XPC and YST were prepared to ensure viable cell cultures which could have been impacted by the $105^{\circ} \mathrm{C}$ drying of the TMR samples that contained them and was sampled from the bunklines. To do this, the DFM yeasts were added to the control diets and mixed in a tumble drier for $12 \mathrm{~min}$.

\subsubsection{Urine}

Only cows with repeated urine samples (i.e., collected in 2 or 3 periods) were used for allantoin (AL) analysis. Urine samples were analyzed by a colorimetric method according to Chen and Gomes (1992). Standards was prepared to create working concentrations of 20, 40, 60, 80 and $100 \mathrm{mg} / \mathrm{L}$ AL. Urine samples were thawed and centrifuged (IEC Centra CL3, Thermo Scientific Inc, Waltham, MA, USA) at $1200 \times g$ for $15 \mathrm{~min}$ at 20 to $22^{\circ} \mathrm{C}$ to remove precipitate which can influence the colorimetric reading. Samples were diluted 60 times to fit the standard curve. A duplicate standard curve was included at the start and end of each run. 
Two inter-run standard samples were used in each run to assess variation among runs but, because all inter-run standards were within 0.1 of the average over all runs, runs were accepted without inter-run correction. Each urine sample was analyzed in duplicate with the average used as the final concentration.

\subsubsection{Blood}

Plasma was sent to the Molecular Structure Facility (University of California, Davis, CA, USA) for physiological AA (i.e., free plasma AA) analysis. Four cows/pen/period, selected from the fecal cow group, were assayed. Samples were acidified with sulfosalicyclic acid to precipitate intact proteins and then AA were quantified using a Hitachi 8800 AA analyzer (Beckman Coulter, Inc., Tokyo, Japan) using lithium citrate buffer and ion-exchange chromatography to separate AA followed by "post-column" ninhydrin reaction detection.

\subsubsection{Feces}

Fecal samples were analyzed for DM, ash, aNDFom, acid detergent fibre (ADF), lignin(sa), starch and CP. All analysis were as described earlier for feed and TMR samples.

\subsubsection{Milk}

Milk fat, true protein and lactose concentrations as well as somatic cell counts (SCC) were determined using infrared spectroscopy at the Dairy Herd Improvement Association laboratory in Hanford (CA, USA).

\subsection{Calculations}

\subsubsection{DM intake}

Dry matter intake was calculated by recording the amount of TMR offered/pen/d for each day during the 7 day collection week and then subtracting all orts to create intake/pen/wk during the collection week. This 'as is weight' was then multiplied by the DM proportion of the TMR to obtain the DM intake/pen/wk. The DM intake/pen/wk was then divided by the sum of the cows/pen/d for the collection week to yield DM intake/cow/d. 


\subsubsection{Urine volume and Daily PD excretion and rumen Microbial CP flow}

Urine volume (L/d) was estimated using an equation derived from data published by Burgos et al. $(2005)$ as: $\quad$ Urine volume $(\mathrm{L})=332.66 \times((\mathrm{SG}-1) \times 1000)^{-0.884}$. Purine derivative (PD) calculations were according to Chen and Gomes (1992). The AL values were first converted from $\mathrm{mg} / \mathrm{l} \mathrm{AL}$ to $\mathrm{mmol} / \mathrm{l} \mathrm{AL}$ and then multiplied by daily urine volume to determine daily $\mathrm{AL}$ excretion/cow followed by calculation of total urine $\mathrm{PD}(\mathrm{mmol} / \mathrm{d})$ excretion as: Milk PD $(\mathrm{mmol} / \mathrm{d})=$ Total urine PD $(\mathrm{mmol} / \mathrm{d}) \times 0.05$, where: AL and uric acid in milk is estimated to be $5 \%$ of that excreted in urine. Total excretion of PD was: $(\mathrm{mmol} / \mathrm{d})=$ Milk PD $(\mathrm{mmol} / \mathrm{d})+$ Total urine PD $(\mathrm{mmol} / \mathrm{d})$. Microbial purines absorbed $(\mathrm{mmol} / \mathrm{d})$ was calculated as: (Urine excretion of PD $\left.(\mathrm{mmol} / \mathrm{d})-0.385 \times \mathrm{BW}^{0.75}\right) / 0.85$, where: $(0.385 \times$ $\mathrm{BW}^{0.75}$ ) is the endogenous PD contribution, $\mathrm{BW}^{0.75}$ is the metabolic body weight of the cow and 0.85 is the recovery of absorbed PD. Finally intestinal flow of microbial $\mathrm{N}(\mathrm{gN} / \mathrm{d})$ was calculated as: Microbial purines absorbed $(\mathrm{mmol} / \mathrm{d}) \times 70 / 0.116 \times 0.83 \times 1000$, where: 70 is the $\mathrm{N}$ content of purines is $70 \mathrm{mg} \mathrm{N} / \mathrm{mmol}$. Digestibility of purines is 0.83 . The ratio of purine- $\mathrm{N}$ : total $\mathrm{N}$ in mixed rumen microbes is taken as 0.116:100 and microbial $\mathrm{CP}$ was calculated as microbial $\mathrm{N} \times 6.25$.

\subsubsection{Production, body condition score and total energetics:}

Milk energy $(\mathrm{MJ} / \mathrm{kg})$ was calculated as: $\{[(41.63 \times \mathrm{g} / \mathrm{kg}$ fat $)+(24.13 \times \mathrm{g} / \mathrm{kg}$ true protein $/ 0.934)+(21.6 \times \mathrm{g} / \mathrm{kg}$ lactose $)-11.72] \times 4.185\} \times 2.2046$, according to Tyrrell and Reid (1965) where 0.934 is the conversion factor from true to crude protein, 4.185 convert Mcal to MJ 2.2046 converts Mcal/lb to Mcal/kg. Milk energy output (MJ/d) was calculated as: Milk energy $(\mathrm{MJ} / \mathrm{kg}) \times$ milk yield $(\mathrm{kg} / \mathrm{d})$.

Differences in BCS were calculated by subtracting the initial from the final BCS for each cow in each period. The energetic value of the BCS change was calculated as: $(\mathrm{BCS} \times$ $300 / 28) \times 4.184$, where: 1 unit BCS change was equal to 300 Mcal net energy for lactation 
(Chilliard et al., 1991) with 4.184 converting Mcal/d to MJ/d. NE maintenance was calculated as: $\left((\mathrm{BW}){ }^{0.75} \times 0.08\right)+$ NEmact $(\mathrm{NRC}, 2001)$, where: $\mathrm{NEmact}=$ variable to calculate NE activity requirements as: $(($ walking distance $/ 1000 \times$ trips $) \times(0.00045 \times \mathrm{W}))+$ $(0.0012 \times \mathrm{BW})$, where: walking distance to milking parlor was $0.5 \mathrm{~km}$, trips is the number of trips to the milking parlor/day, BW was assumed to be $675 \mathrm{~kg}$. The $\mathrm{NE}_{\mathrm{L}}$ density $(\mathrm{MJ} / \mathrm{kg} \mathrm{DM})$ of TMR's was estimated using the biological response of the cows, as expressed in the partial NE output, and measured DM intake as: NE output (MJ/d) / DM intake (kg/d).

\subsubsection{Whole tract nutrient digestibility}

Whole tract nutrient digestibility was calculated as: $1000-(1000 \times((\mathrm{g} / \mathrm{kg} \operatorname{lignin}(\mathrm{sa})$ $\mathrm{TMR} \times 0.95 / \mathrm{g} / \mathrm{kg}$ lignin $(\mathrm{sa})$ faeces $) \times(\mathrm{g} / \mathrm{kg}$ nutrient faeces $/ \mathrm{g} / \mathrm{kg}$ nutrient $\mathrm{TMR})))$, assuming that lignin(sa) in the TMR is $950 \mathrm{~g} / \mathrm{kg}$ indigestible and will be recovered in faeces (Stensig and Robinson, 1997).

\subsubsection{In vitro gas production}

Gas production (ml/g OM) was calculated as: ((gas production/h since last recording) (Blank piston hour since last recording)) / (TMR analytical DM, g/kg) / (TMR OM, g/kg). The ME $(\mathrm{MJ} / \mathrm{Kg} \mathrm{DM})$ was calculated as: $\mathrm{ME}(\mathrm{MJ} / \mathrm{kg} \mathrm{DM})=1.25+(0.0292 \times 24 \mathrm{~h}$ gas $(\mathrm{ml}))$ $+(0.0246 \times \mathrm{g} / \mathrm{kg}$ fat $)+(0.0143 \times(\mathrm{g} / \mathrm{kg} \mathrm{CP}-\mathrm{g} / \mathrm{kg}$ ADICP $))$, according to Robinson et al. (2004).

\subsection{Statistical analysis}

For all statistical analysis only cows that were in their originally assigned pens for each of the 26 consecutive Dairy Comp 305 (Valley Ag Software, Tulare, CA, USA) herd data backups during the 12 wk study were used. Any cow that moved from their originally assigned pen for any reason was not included. This resulted in an initial group of 386 cows for milk production, 329 cows for BCS and 64 cows for urine based response parameters. Outlier analysis completed blind to treatments identified 20 cows: 11 cows from the milk data 
set, 8 from the BCS dataset, and 1 from the urine dataset. This resulted in a total number of cows used for statistical analysis of 375 for milk production, 321 for BCS and 63 cows for urine parameter analysis.

A normal distribution of all animal based response parameters was confirmed prior to statistical analysis. Animal production data, BCS, SG, urine volume, urine AL, microbial CP flow and plasma AA were analyzed using the MIXED Model of SAS (2000) for a $3 \times 3$ Latin Square design with cow within the pen as the random effect, and period, pen and treatment as fixed effects. For DM intake ( $n=3$ pens, calculated on a pen basis with 3 pens/period), TMR components and composition, TMR nutrient profile and whole tract digestibility the General Linear Model (GLM) of SAS (2000) was used with period, pen and treatment as fixed effects. Differences between each treatment and the Control used predetermined contrasts (Steel and Torrie, 1960).

For the in vitro gas production values at $4,24,30$ and $48 \mathrm{~h}$ of incubation, as well as the calculated ME, the GLM model of SAS (2000) was used with pen, period and treatment as class variables, and differences between treatments and control were assessed using predetermined contrasts as described above.

Significance of differences between each DFM yeast treatment and the Control used the PDIFF function in SAS (2000), with $0.05<P<0.10$ accepted as a tendency to differ and $P<$ 0.05 as indicator of a significant difference.

\section{Results}

\subsection{Ration evaluation}

The nutrient profile of the feeds (Tables 1 and 2) are generally similar to California feeds as reported by Swanepoel et al. (2010) and Rauch et al. (2012) and similar to feeds listed in NRC (2001). The TMR of the three treatment diets were similar in ingredient (Table 3) and 
nutrient (Table 4) composition and there were no differences among them. The only substantive difference between diets was addition of the DFM yeast additives.

\section{Table 1}

Chemical analysis ( \pm standard deviation ${ }^{\mathrm{b}}$ ) of forage and wet byproduct ingredients used in the total mixed rations fed to dairy cows $(\mathrm{g} / \mathrm{kg} \mathrm{DM}){ }^{\mathrm{a}}$

\begin{tabular}{|c|c|c|c|c|c|c|}
\hline & $\begin{array}{l}\text { Alfalfa, (hay) } \\
(\mathrm{HQ})^{\mathrm{c}}\end{array}$ & $\begin{array}{l}\text { Alfalfa, } \\
\text { (hay) } \\
(\text { MQ) }\end{array}$ & $\begin{array}{l}\text { Wheat } \\
\text { silage }\end{array}$ & $\begin{array}{l}\text { Corn } \\
\text { silage }\end{array}$ & $\begin{array}{l}\text { Alfalfa } \\
\text { fresh chop }\end{array}$ & $\begin{array}{l}\text { Citrus } \\
\text { pulp }\end{array}$ \\
\hline \multirow{2}{*}{ Dry matter } & 933 & 938 & 318 & 311 & 266 & 152 \\
\hline & (3.4) & (7.9) & (13.2) & (3.5) & (16.1) & $(30.0)$ \\
\hline \multirow[t]{2}{*}{ Organic matter } & 876 & 891 & 880 & 932 & 895 & 956 \\
\hline & (10.3) & (11.4) & (3.7) & $(1.3)$ & (39.4) & $(5.8)$ \\
\hline \multirow{2}{*}{ Crude protein. } & 215 & 211 & 104 & 76 & 216 & 82 \\
\hline & (8.3) & (27.9) & (3.4) & (1.4) & (2.0) & (5.6) \\
\hline \multirow[t]{2}{*}{ aNDFom $^{\mathrm{e}}$} & 321 & 362 & 503 & 436 & 333 & 198 \\
\hline & $(16.0)$ & $(31.0)$ & (33.3) & $(5.9)$ & $(42.1)$ & (45.7) \\
\hline
\end{tabular}

${ }^{a}$ Average of a total of 6 samples, 2 samples collected during the last week of each of the 3 periods.

${ }^{\mathrm{b}}$ Standard deviation of the mean.

${ }^{\mathrm{c}}$ High quality alfalfa hay as classified by the dairy.

${ }^{\mathrm{d}}$ Medium quality alfalfa hay as classified by the dairy.

${ }^{\mathrm{e}}$ Neutral detergent fiber assayed with heat stable amylase expressed exclusive of residual ash.

Table 2

Chemical analysis ( \pm standard deviation ${ }^{b}$ ) of concentrate and premix ingredients used in the total mixed rations fed to

\begin{tabular}{lccccccc}
\hline & $\begin{array}{c}\text { Corn } \\
\text { (rolled grain) }\end{array}$ & $\begin{array}{c}\text { Almond } \\
\text { hulls }\end{array}$ & $\begin{array}{c}\text { Cottonseed, } \\
\text { (whole upland) }\end{array}$ & $\begin{array}{c}\text { Canola } \\
\text { (pellets) }\end{array}$ & $\begin{array}{c}\text { Alfalfa } \\
\text { (hay) (LQ) }\end{array}$ & $\begin{array}{c}\text { Wheat } \\
\text { straw }\end{array}$ & $\begin{array}{c}\text { DDGS } \\
(\text { meal) }\end{array}$ \\
\hline Dry matter & 848 & 944 & 889 & 919 & 938 & 955 & 907 \\
Organic matter & $(4.6)$ & $(1.5)$ & $(10.0)$ & $(3.0)$ & $(2.1)$ & $(8.4)$ & $(1.2)$ \\
& 987 & 904 & 953 & 924 & 888 & 881 & 945 \\
Crude protein & $(0.1)$ & $(42.9)$ & $(1.2)$ & $(2.7)$ & $(3.0)$ & $(0.3)$ & $(1.3)$ \\
& 82 & 51 & 296 & 407 & 167 & 40 & 315 \\
aNDFom $^{\mathrm{e}}$ & $(1.9)$ & $(2.3)$ & $(2.6)$ & $(5.8)$ & $(6.6)$ & $(0.4)$ & $(4.0)$ \\
& 90 & 285 & 462 & 215 & 441 & 722 & 288 \\
& $(8.0)$ & $(34.0)$ & $(10.2)$ & $(3.1)$ & $(33.9)$ & $(3.0)$ & $(9.5)$ \\
\hline
\end{tabular}

${ }^{a}$ Average of a total of 6 samples, 2 samples collected during the last week of each of the 3 periods.

${ }^{\mathrm{b}}$ Standard deviation of the mean.

${ }^{\mathrm{c}}$ Low quality alfalfa hay as classified by the dairy.

${ }^{\mathrm{d}}$ Dried distillers grains with solubles (corn grain).

${ }^{\mathrm{e}}$ Neutral detergent fiber assayed with heat stable amylase expressed exclusive of residual ash. 
Table 3

Ingredient composition ( $/ \mathrm{kg} \mathrm{DM})$ of the TMR fed to high producing dairy cows: Control (C), XPC (XPC) and Yeasture (YST) treatments. ${ }^{a}$

\begin{tabular}{lcccc}
\hline & \multicolumn{3}{c}{ Treatments } & \\
\cline { 2 - 4 } & C & XPC & YST & SEM $^{\text {c }}$ \\
\hline Alfalfa, Hay (HQ) $^{\text {d }}$ & 44.3 & 45.1 & 44.5 & 0.34 \\
Alfalfa, Hay (MQ) $^{\mathrm{e}}$ & 48.4 & 47.3 & 46.6 & 0.92 \\
Wheat, silage (Whole crop) & 134.0 & 133.8 & 134.8 & 0.27 \\
Corn, silage (Whole crop) $_{\text {Corn, grain (rolled) }}$ & 128.1 & 128.7 & 128.5 & 0.33 \\
Citrus, Pulp (with orange and lemon) & 190.6 & 190.2 & 190.9 & 0.03 \\
Alfalfa (fresh chop) & 29.5 & 29.4 & 29.3 & 0.08 \\
Almond, hulls $^{\mathrm{b}}$ & 32.5 & 33.2 & 32.1 & 4.68 \\
Cottonseed, whole upland $^{\mathrm{b}}$ & 100.7 & 100.7 & 100.8 & 0.32 \\
Mineral, premix $^{\mathrm{b}}$ & 44.9 & 44.9 & 44.9 & 0.14 \\
Canola meal (solvent extracted) $^{\mathrm{b}}$ & 14.8 & 14.8 & 14.8 & 0.05 \\
Alfalfa hay (LQ) or Wheat straw $^{\mathrm{b}}$ & 135.6 & 135.6 & 135.7 & 0.43 \\
Sodium Bicarbonate $^{\mathrm{b}}$ & 16.4 & 16.4 & 16.4 & 0.05 \\
Fat, rumen inert $^{\text {bf }}$ & 4.7 & 4.7 & 4.7 & 0.01 \\
DDGS $^{\text {bg }}$ & 10.4 & 10.4 & 10.4 & 0.03 \\
Molasses (liquid) $^{\mathrm{b}}$ & 68.6 & 68.5 & 68.6 & 0.22 \\
\hline
\end{tabular}

XPC yeast culture (XPC; Diamond V Mills, Cedar Rapids, IA, USA), Yeasture direct fed microbial (YST; Cenzone Tech, Inc., San Marcos, CA, USA).

${ }^{\text {a }}$ Based on two TMR samples collected/period/diet (i.e., 6 samples per diet). Additions of the DFM yeast products were too low to provide meaningful additions to the diet on a DM basis.

${ }^{\mathrm{b}}$ Ingredients used to create premix.

${ }^{\mathrm{c}}$ Standard error of the mean.

${ }^{\mathrm{d}}$ High quality alfalfa hay as classified by the dairy.

${ }^{\mathrm{e}}$ Medium quality alfalfa hay as classified by the dairy.

${ }^{\mathrm{f}}$ Energy 2. Virtus Nutrition, LLC. 520 Industrial Way, Corcoran, CA, USA.

${ }^{\mathrm{g}}$ Dried distillers grains with solubles (corn grain).

No significant differences occurred among diets. 
Table 4

Nutrient profile of the TMR fed to high producing dairy cows fed the Control (C), XPC (XPC) and Yeasture (YST) treatments. ${ }^{\text {a }}$

\begin{tabular}{|c|c|c|c|c|}
\hline & \multicolumn{3}{|c|}{ Treatments } & \multirow[b]{2}{*}{ SEM } \\
\hline & $\mathrm{C}$ & XPC & YST & \\
\hline Dry matter (g/kg as fed) & 523 & 521 & 525 & 12.1 \\
\hline \multicolumn{5}{|l|}{$\mathrm{g} / \mathrm{kg} \mathrm{DM}$} \\
\hline Crude protein & 166 & 167 & 163 & 1.8 \\
\hline $\mathrm{ADICP}^{\mathrm{c}}$ & 79 & 78 & 77 & 1.4 \\
\hline aNDFom $^{d}$ & 308 & 312 & 315 & 3.5 \\
\hline $\mathrm{ADF}$ & 229 & 233 & 235 & 1.3 \\
\hline $\operatorname{Lignin}(\mathrm{sa})^{\mathrm{e}}$ & 50 & 51 & 52 & 1.2 \\
\hline Crude fat & 44 & 45 & 45 & 0.9 \\
\hline Starch & 179 & 172 & 169 & 11.1 \\
\hline Free sugars & 35 & 36 & 37 & 2.9 \\
\hline Ash & 91 & 90 & 90 & 0.9 \\
\hline $\mathrm{Ca}$ & 9.0 & 9.4 & 9.2 & 0.22 \\
\hline $\mathrm{Mg}$ & 3.0 & 2.9 & 3.0 & 0.03 \\
\hline $\mathrm{K}$ & 16.3 & 16.2 & 16.4 & 0.22 \\
\hline $\mathrm{P}$ & 4.2 & 4.1 & 4.1 & 0.07 \\
\hline S & 3.0 & 2.9 & 2.9 & 0.02 \\
\hline $\mathrm{Na}$ & 3.7 & 3.8 & 3.7 & 0.04 \\
\hline $\mathrm{Cl}$ & 5.3 & 5.4 & 5.3 & 0.16 \\
\hline \multicolumn{5}{|l|}{$\mathrm{mg} / \mathrm{kg} \mathrm{DM}$} \\
\hline $\mathrm{Zn}$ & 85 & 87 & 85 & 0.7 \\
\hline $\mathrm{Mn}$ & 50 & 51 & 51 & 0.5 \\
\hline $\mathrm{Cu}$ & 17 & 17 & 17 & 0.3 \\
\hline Co & 0.50 & 0.48 & 0.53 & 0.010 \\
\hline Mo & 1.37 & 1.38 & 1.34 & 0.020 \\
\hline $\mathrm{Se}$ & 0.48 & 0.49 & 0.50 & 0.009 \\
\hline $\mathrm{Fe}$ & 395 & 421 & 459 & 0.8 \\
\hline
\end{tabular}

XPC yeast culture (XPC; Diamond V Mills, Cedar Rapids, IA, USA), Yeasture direct fed microbial (YST; Cenzone Tech, Inc., San Marcos, CA, USA).

${ }^{a}$ Based on 2 TMR samples collected/period/diet (i.e., 6 samples per diet).

${ }^{\mathrm{b}}$ Standard error of the mean.

${ }^{\mathrm{c}}$ Acid detergent insoluble crude protein expressed as $\mathrm{g} / \mathrm{kg} \mathrm{CP}$.

${ }^{\mathrm{d}}$ aNDF expressed exclusive of residual ash.

${ }^{\mathrm{e}}$ Lignin assayed with sulfuric acid.

No significant differences occurred among diets. 


\subsection{Milk yield, milk composition and BCS}

There was a milk yield response $(P=0.01)$ when YST was fed (Table 5), which included increases in yields of true protein $(P=0.01)$, lactose $(P=0.01)$ and energy $(P=0.02)$, as well as a tendency $(P=0.07)$ for a milk fat yield increase. The composition of the milk $(\mathrm{g} / \mathrm{kg})$, as well as the SCC level, was not affected by YST. In contrast, there was no impact on any parameter when XPC was fed. There was no difference in average BCS, or BCS change, versus Control, for either yeast product.

\subsection{Energy balance}

Yeasture feeding increased $(P=0.02)$ milk energy output compared to Control, but there was no effect of XPC (Table 6.) With both YST and XPC there was an increased $(P<0.01)$ total $\mathrm{NE}$ output/d, although diet $\mathrm{NE}_{\mathrm{L}}$ density for both treatments versus Control did not differ.

\subsection{Dry matter intake and digestibility}

It is clear that there was no DM intake response to either treatment and no difference in fecal DM proportion (Table 7), but there was a reduction in apparent total tract digestibility of OM with YST $(P=0.02)$, a tendency for OM digestibility to decrease with XPC $(P=$ 0.08), a decrease in apparent CP digestibility with YST $(P<0.01)$ and a tendency to decreased apparent CP digestibility for XPC $(P=0.05)$. In contrast, there were no differences in apparent starch and aNDFom digestibility.

\subsection{In vitro gas production}

There were no differences between the Control diet gas production and that of the treatment diets, or when comparing the treatments to each other (Table 8). Comparing these diets to those of Rauch et al. (2012), ours were more fermentable, as judged by higher gas production. 
Table 5

Production performance and BCS of high producing dairy cows fed the Control (C), XPC (XPC) and Yeasture (YST) treatments.

\begin{tabular}{|c|c|c|c|c|c|c|}
\hline & \multicolumn{3}{|c|}{ Treatments } & \multirow[b]{2}{*}{ SEM $^{\mathrm{a}}$} & \multicolumn{2}{|c|}{$P$} \\
\hline & $\mathrm{C}$ & XPC & YST & & C vs. XPC & C vs. YST \\
\hline \multicolumn{7}{|l|}{ Yield $(\mathrm{kg} / \mathrm{d})^{\mathrm{b}}$} \\
\hline Milk & 47.77 & 47.92 & 48.93 & 0.412 & 0.75 & 0.01 \\
\hline Fat & 1.56 & 1.56 & 1.59 & 0.016 & 0.94 & 0.07 \\
\hline True protein & 1.35 & 1.36 & 1.39 & 0.011 & 0.39 & 0.01 \\
\hline Lactose & 2.27 & 2.28 & 2.33 & 0.020 & 0.62 & 0.01 \\
\hline Energy (MJ/d) & 132.3 & 132.7 & 135.5 & 1.14 & 0.76 & 0.02 \\
\hline \multicolumn{7}{|l|}{ Composition $(\mathrm{g} / \mathrm{kg})^{\mathrm{b}}$} \\
\hline Fat & 3.28 & 3.26 & 3.27 & 0.028 & 0.53 & 0.84 \\
\hline True protein & 2.85 & 2.86 & 2.85 & 0.011 & 0.29 & 0.75 \\
\hline Fat : Protein ratio & 1.15 & 1.14 & 1.15 & 0.008 & 0.27 & 0.85 \\
\hline Lactose & 4.76 & 4.76 & 4.75 & 0.008 & 0.52 & 0.43 \\
\hline Energy $(\mathrm{MJ} / \mathrm{kg})$ & 2.78 & 2.78 & 2.78 & 0.013 & 0.75 & 0.75 \\
\hline $\mathrm{SCC}(\times 1000$ cells $/ \mathrm{ml})$ & 65.2 & 68.8 & 79.1 & 9.18 & 0.71 & 0.16 \\
\hline \multicolumn{7}{|l|}{ Body Condition $^{c}$} \\
\hline BCS (units) & 2.48 & 2.46 & 2.48 & 0.023 & 0.24 & 0.93 \\
\hline Change in BCS (units/28 d) & 0.08 & 0.10 & 0.07 & 0.014 & 0.15 & 0.85 \\
\hline
\end{tabular}

XPC yeast culture (XPC; Diamond V Mills, Cedar Rapids, IA, USA), Yeasture direct fed microbial (YST; Cenzone Tech, Inc., San Marcos, CA, USA).

${ }^{a}$ Standard error of the mean.

${ }^{\mathrm{b}} n=375$ cows.

${ }^{\mathrm{c}} n=321$ cows. 
Table 6

Energy balance of high producing dairy cows fed the Control (C), XPC (XPC) and Yeasture (YST) treatments.

\begin{tabular}{lccccccc}
\hline & \multicolumn{3}{c}{ Treatments } & & \multicolumn{2}{c}{$P$} \\
\cline { 2 - 3 } & $\mathrm{C}$ & XPC & YST & SEM $^{\text {a }}$ & C vs. XPC & C vs. YST \\
\hline Milk energy output (MJ/d) & 132.3 & 132.7 & 135.5 & 1.14 & 0.76 & 0.02 \\
BCS energy (MJ/d) & 3.4 & 4.7 & 3.2 & 0.63 & 0.15 & 0.85 \\
Total net energy (MJ/d) & 185.5 & 187.1 & 188.4 & 0.13 & 0.01 & $<0.01$ \\
$\mathrm{NE}_{\mathrm{L}}(\mathrm{MJ} / \mathrm{Kg} \mathrm{DM})$ & 6.80 & 6.94 & 6.91 & 0.164 & 0.59 & 0.66 \\
\hline
\end{tabular}

XPC yeast culture (XPC; Diamond V Mills, Cedar Rapids, IA, USA), Yeasture direct fed microbial (YST;

Cenzone Tech, Inc., San Marcos, CA, USA).

${ }^{\text {a }}$ Standard error of the mean.

${ }^{\mathrm{b}}$ Maintenance energy assumed to be 49.7 for all treatments.

$n=3$ pens.

Table 7

Dry matter intake, fecal dry matter and total tract digestibility of TMR and chemical components for dairy cows fed the Control (C), XPC (XPC) and Yeasture (YST) treatments.

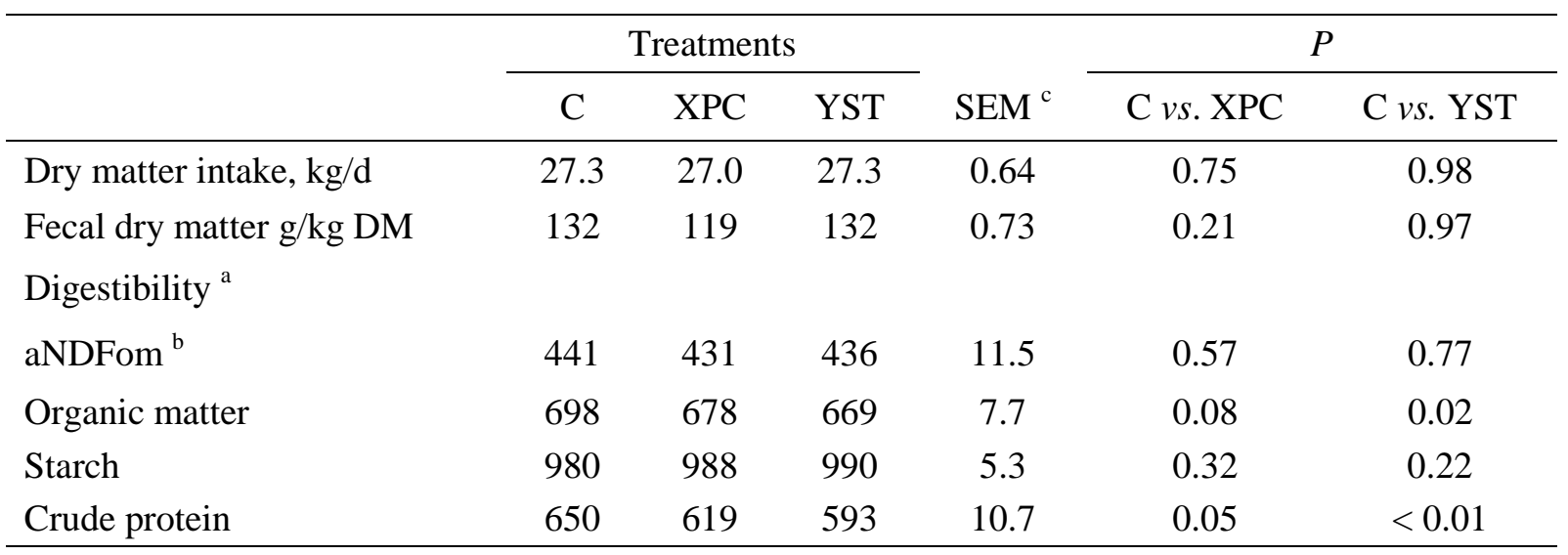

XPC yeast culture (XPC; Diamond V Mills, Cedar Rapids, IA, USA), Yeasture direct fed microbial (YST;

Cenzone Tech, Inc., San Marcos, CA, USA).

${ }^{a}$ Based on two TMR samples collected/period/diet (i.e., 6 samples/diet).

${ }^{\mathrm{b}}$ aNDF expressed exclusive of residual ash.

${ }^{\mathrm{c}}$ Standard error of the mean. 
Table 8

In Vitro gas production and predicted ME of the diets for dairy cows fed the Control (C), XPC (XPC) and Yeasture (YST) treatments.

\begin{tabular}{ccccccc}
\hline & \multicolumn{5}{c}{ Treatments $^{\text {a }}$} \\
\cline { 2 - 5 } & $\mathrm{C}$ & XPC & YST & $\begin{array}{c}\text { C }+ \\
\text { XPC }\end{array}$ & C + YST & SEM $^{\text {b }}$ \\
\hline Gas production at (ml/g OM) & & & & & & \\
$4 \mathrm{~h}$ & 89 & 92 & 91 & 92 & 93 & 2.4 \\
$24 \mathrm{~h}$ & 296 & 304 & 304 & 305 & 306 & 6.1 \\
$30 \mathrm{~h}$ & 319 & 326 & 329 & 326 & 330 & 6.8 \\
$48 \mathrm{~h}$ & 350 & 348 & 360 & 360 & 363 & 8.3 \\
$\mathrm{ME}^{\mathrm{c}}, 1 \times \mathrm{M}$ & 9.9 & 10.1 & 10.2 & 10.2 & 10.2 & 0.18 \\
\hline
\end{tabular}

XPC yeast culture (XPC; Diamond V Mills, Cedar Rapids, IA, USA), Yeasture direct fed microbial (YST;

Cenzone Tech, Inc., San Marcos, CA, USA).

a ' $\mathrm{C}$ ', 'XPC' and 'YST' is samples of the diets fed to the cows which were dried and ground. 'C + $\mathrm{XPC}$ ' and ' $\mathrm{C}+$ YST' are samples of the control diet which was dried and ground and then had XPC and YST added to recreate the XPC and YST diets, but without the XPC and YST having been oven dried.

${ }^{\mathrm{b}}$ Standard error of the mean.

${ }^{c}$ UC Davis approach to estimate ME (MJ/kg DM) of a feed (Robinson et al., 2004). 1× M, ME requirements for maintenance.

\section{Table 9}

Urine SG, volume, measured allantoin and calculated microbial CP flow from the rumen in dairy cows fed the Control (C), XPC (XPC) and Yeasture (YST) treatments.

\begin{tabular}{lccccccc}
\hline & \multicolumn{3}{c}{ Treatments } & & \multicolumn{2}{c}{$P$} \\
\cline { 2 - 3 } & C & XPC & YST & SEM $^{\text {a }}$ & C vs. XPC & C vs. YST \\
\hline Specific gravity (SG) & 1.027 & 1.028 & 1.027 & 0.0006 & & 0.35 & 0.55 \\
Urine volume (L/d) & 18.4 & 18.1 & 18.9 & 0.45 & & 0.50 & 0.46 \\
Measured Al concentration (mg/L) & 59.1 & 62.1 & 59.1 & 1.94 & & 0.17 & 0.99 \\
Microbial CP flow & 2239 & 2309 & 2286 & 47.1 & & 0.16 & 0.37 \\
\hline
\end{tabular}

XPC yeast culture (XPC; Diamond V Mills, Cedar Rapids, IA, USA), Yeasture direct fed microbial (YST; Cenzone Tech, Inc., San Marcos, CA, USA).

${ }^{a}$ Standard error of the mean. $n=63$ cows. 
Table 10

Free amino acid concentrations $(\mu \mathrm{g} / \mathrm{ml})$ in plasma of dairy cows fed the Control $(\mathrm{C})$, XPC (XPC) and Yeasture (YST) treatments.

\begin{tabular}{|c|c|c|c|c|c|c|}
\hline & \multicolumn{3}{|c|}{ Treatments } & \multirow[b]{2}{*}{ SEM $^{\mathrm{a}}$} & \multicolumn{2}{|c|}{$P$} \\
\hline & $\mathrm{C}$ & XPC & YST & & C vs. XPC & C vs. YST \\
\hline \multicolumn{7}{|l|}{$n=12 \operatorname{cows}^{b}$} \\
\hline \multicolumn{7}{|l|}{ Essential amino acids } \\
\hline Threonine & 10.9 & 11.3 & 13.2 & 0.71 & 0.69 & 0.03 \\
\hline Valine & 28.2 & 27.2 & 31.6 & 1.83 & 0.55 & 0.08 \\
\hline Methionine & 3.53 & 3.43 & 4.02 & 0.202 & 0.73 & 0.11 \\
\hline Isoleucine & 13.8 & 12.9 & 15.3 & 0.92 & 0.33 & 0.16 \\
\hline Leucine & 21.7 & 20.2 & 23.8 & 1.25 & 0.31 & 0.17 \\
\hline Phenylalanine & 8.5 & 7.6 & 9.0 & 0.40 & 0.10 & 0.41 \\
\hline Tryptophan & 12.2 & 13.5 & 14.2 & 0.68 & 0.14 & 0.02 \\
\hline Lysine & 10.9 & 10.1 & 12.2 & 0.68 & 0.37 & 0.14 \\
\hline Histidine & 6.6 & 7.4 & 7.7 & 0.44 & 0.17 & 0.06 \\
\hline Arginine & 12.2 & 11.8 & 13.6 & 0.71 & 0.73 & 0.13 \\
\hline Total essential amino acids & 129 & 125 & 145 & 6.5 & 0.69 & 0.07 \\
\hline Lys: Met ratio & 3.1 & 3.0 & 3.1 & 0.14 & 0.28 & 0.92 \\
\hline \multicolumn{7}{|l|}{ Non-essential amino acids } \\
\hline Homocystine & 0.67 & 0.77 & 0.62 & 0.061 & 0.13 & 0.45 \\
\hline Aspartic acid & 1.1 & 1.2 & 1.2 & 0.07 & 0.59 & 0.70 \\
\hline Tyrosine & 9.02 & 8.75 & 10.7 & 0.61 & 0.75 & 0.05 \\
\hline Serine & 7.5 & 8.0 & 8.8 & 0.50 & 0.46 & 0.07 \\
\hline Glutamic acid & 6.0 & 5.8 & 6.4 & 0.27 & 0.63 & 0.18 \\
\hline Glutamine & 39.3 & 42.2 & 40.8 & 3.09 & 0.51 & 0.73 \\
\hline Glycine & 22.2 & 25.3 & 27.2 & 2.16 & 0.18 & 0.04 \\
\hline Alanine & 20.3 & 19.5 & 22.5 & 1.20 & 0.65 & 0.19 \\
\hline Proline & 11 & 11.1 & 12.6 & 0.62 & 0.85 & 0.06 \\
\hline Asparagine & 4.5 & 4.8 & 5.4 & 0.30 & 0.43 & 0.03 \\
\hline Taurine & 5.7 & 6.6 & 6.9 & 0.49 & 0.19 & 0.07 \\
\hline Total non-essential amino acids & 127 & 134 & 143 & 7.2 & 0.51 & 0.13 \\
\hline
\end{tabular}

XPC yeast culture (XPC; Diamond V Mills, Cedar Rapids, IA, USA), Yeasture direct fed microbial (YST; Cenzone Tech, Inc., San Marcos, CA, USA).

${ }^{\text {a }}$ Standard error of the mean.

${ }^{\mathrm{b}}$ A group of 4 cows/pen/period randomly selected from the group of eligible blood cows and sent for AA analysis as this was determined to be sufficient to identify significant differences between treatments and the control. 


\subsection{Urine $S G$, volume, measured allantoin and calculated $C P$ flow}

There was no difference in any urine data (i.e., SG, urine volume, allantoin concentrations and calculated microbial CP flow) due to addition of either DFM yeast product (Table 9).

\subsection{Blood plasma amino acid concentrations}

When comparing each DFM additive with Control, total essential AA (EAA) tended to be higher $(P=0.07)$ when cows were fed YST. This higher level of EAA was mainly driven by an increase in threonine $(P=0.03)$ tryptophan $(P=0.02)$, valine $(P=0.08)$ and histidine $(P=$ 0.06). Although total NEAA concentrations did not differ with YST, there was an increase in concentrations of glycine $(P=0.04)$, asparagine $(P=0.03)$, tyrosine $(P=0.05)$, serine $(P=$ $0.07)$, proline $(P=0.06)$ and taurine $(P=0.07)$. In contrast, when cows were fed XPC, there were no differences in blood AA concentrations (Table 10).

\section{Discussion}

\subsection{Diet and DFM yeasts interactions}

The ingredient and nutrient profiles of the diets are very similar to those reported by Swanepoel et al. (2014) and Rauch et al. (2012). That the diet was composed of 16 ingredients may explain the low variation in inclusion rates of ingredients and nutrients. Overall, the basal experimental TMR was judged to be representative of typical California dairy rations and the TMR complies with the nutritional requirements of large breed dairy cows at a similar level of production, with a small oversupply of most micro minerals (NRC, 2001).

The aNDFom of the canola pellets were slightly lower than reported by Swanepoel et al. (2010), but within the NRC (2001) range. The low quality alfalfa hay had a higher 
concentration of aNDFom compared to Swanepoel et al. (2010), but was within the range reported by Rauch et al. (2012).

Desnoyers et al. (2009), in a review article on modes of action of live yeast and yeast culture products on rumen parameters and milk production, discussed differences among experiments that might affect treatment response. They concluded that the positive effect of live yeast and yeast culture supplementation on DM intake increased as the proportion of concentrate in the diet increased. Factors that affected milk yield responses were DM intake level as well as diet concentrate, NDF and CP levels. When comparing our diet to other studies where a DM intake response occurred, it is clear that they were generally diets with lower fibre levels compared to our study with its relatively high fibre levels, and this might explain the lack of an intake response. Robinson and Erasmus (2008) found that increased dietary fibre levels have a strong effect on suppressing the DM intake and production response when live yeast and yeast culture products are fed to dairy cows. Williams and Newbold (1990) suggested that live yeasts appear to be more beneficial when high starch diets are fed during early lactation and suggested that this benefit was based on the ability of yeast cultures to moderate rumen lactate concentrations. In contrast, our treatments had a positive effect on animal performance when the treatments were supplemented to a low starch diet indicating the importance of considering product specific response, and emphasizing that many factors affect the animal production response.

The $\mathrm{NE}_{\mathrm{L}}$ values for the experimental diets are normal for diets fed to this class of cows and within ranges suggested by the NRC (2001). While it is clear that both YST and XPC had an effect on NE output, their modes of action differed with YST primarily impacting milk energy output whereas XPC fed cows had a higher BCS energy output, leading to similar diet $\mathrm{NE}_{\mathrm{L}}$ densities for the two yeast treatments. 


\subsection{Effects of Yeasture supplementation}

Because there is only one published study that used Yeasture (Stretenovic et al., 2008), and because it is a unique product containing S.cerevisiae, B. subtilis and A. oryzae fermentation extracts, it makes comparisons of our results to those of others impossible. Nevertheless our results can be compared to other live yeast (S. cerevisiae) products as Yeasture is a live yeast based product, as well as bacterial 'cocktails' that were composed of similar bacterial species such as B. subtilis and A. oryzae fermentation extracts.

The only published study which utilized Yeasture as a supplement for lactating dairy cows (Stretenovic et al., 2008), who reported a $2.6 \mathrm{~kg}$ increase in $4 \%$ fat corrected milk when fed to early lactation cows. This is similar to our $1.2 \mathrm{~kg} / \mathrm{d}$ increase in milk yield. However, in contrast to Stretenovic et al. (2008), milk fat and lactose composition $(\mathrm{g} / \mathrm{kg})$ did not change in our study and this is in agreement with Bitencourt et al. (2011) who fed a live yeast. In contrast to our results, Kristensen et al. (2014) reported no difference in milk production when a live yeast product was fed to dairy cows, but found that its addition decreased milk protein concentrations, which is also in agreement with a literature review by Robinson (2013) which showed that addition of live yeast decreases milk CP \%. Erasmus et al. (1992), Higginbotham et al. (1999) and Soder and Holden (1999) found no effects on milk production or milk components when live yeast products were fed to dairy cows, but Higginbotham et al. (1999) found that, due to a numerical increase in milk yield and some milk components, that there was an increase in milk fat, protein and solids nonfat yield when a live yeast product was fed. In contrast to our data, Stretenovic et al. (2008) fed Yeasture and found lower milk SCC. This is consistent with Higginbotham et al. (1999) who showed a tendency for SCC to decrease when live yeast was fed. As the SCC values were very low in our study, suggesting mastitis in the herd was low, it was perhaps unlikely that there was an opportunity to decrease it further. 
Higginbotham et al. (1999) reported no effect on BCS when a live yeast product was fed, which is in agreement with Soder and Holden (1999) and our results. In a literature review on effects of yeast products on the performance of lactating and growing animals, Robinson (2013) reported a slight increase in body weight gain with live yeast product feeding.

Erasmus et al. (1992) showed that AA in digesta flow from the rumen was higher when cows were fed a live yeast. As the AA that drove this increase was threonine, serine, glutamic acid and cysteine, they concluded that this change was mainly due to the increase in measured microbial CP flow from the rumen. Dawson et al. (1990) stated that yeast cultures might influence the AA profile flowing from the rumen by selectively stimulating some species of anaerobic bacteria. Purser and Buechler (1966) investigated the AA composition of rumen bacteria and determined that the AA composition of a mixture of bacteria in the rumen is relatively constant, but noted that when individual species of rumen bacteria were compared to each other, differences did occur. A comparison of the AA compositions of the four abundant rumen bacteria Selenomonas ruminantium, Butyrivibrio fibrisolvens, Bacteroides amylophilus, and Bacteroides ruminicola shows that large differences in concentrations of some AA occur, thereby suggesting that any feed supplement with a selective stimulatory effect on growth of bacterial species in the rumen could cause a population shift that can lead to an alteration in the AA profile of the rumen bacterial fraction (Erasmus et al., 1992).

However, data from our study shows that there was no influence on microbial CP flow (g/d) from the rumen with YST, which is in agreement with Soder and Holden (1999) and Bitencourt et al. (2011) who found no effect on the urine creatinine to allantoin ratio when a live yeast product was fed. In contrast, Erasmus et al. (1992) showed a tendency to increase non-ammonia $\mathrm{N}$ flow from the rumen when diets were supplemented with a live yeast. Dawson et al. (1990) showed an increase in cellulolytic bacteria numbers in rumen contents 
of steers fed a forage diet supplemented with a live yeast, and this is in agreement with Robinson (2013) who, in a review article, showed that rumen bacterial counts of both cellulolytic and non-cellulolytic bacteria increased with live yeast supplementation. Although a DFM yeast impact on the rumen bacteria species profile cannot be eliminated as a possible treatment response, it seems unlikely if total rumen MCP outflow was not impacted.

The in vitro gas production of the treatment diets through $48 \mathrm{~h}$ shows that there was no immediate effect of DFM yeast on rumen fermentation. Lila et al. (2004) found a linear increase in gas production as a live yeast supplementation level increased, but it did not seem to differ at lower levels of addition. That our total tract apparent digestibility data show no difference in the digestion of aNDFom further supports our conclusion that there was no change in fermentation in the rumen, while discounting the possibility of a bacterial species shift being responsible for the increased concentration of some AA in blood plasma.

Williams and Newbold (1990) suggested that live yeasts may alter site of nutrient digestion and this might affect apparent total tract digestibility leading to inaccurate representation of the effect of yeast cultures on digestion. This can be seen in our study where whole tract $\mathrm{OM}$ and $\mathrm{CP}$ apparent digestibility decreased with the YST treatment. Kristensen et al. (2014) reported no effect on NDF and OM digestibility in dairy cows fed live yeasts, which is consistent with Erasmus et al. (1992), but also contrasts to their data which showed an increase in apparent $\mathrm{CP}$ and $\mathrm{ADF}$ digestion when a live yeast culture was fed. Chiquette (1995) fed a combination of $A$. oryzae and live $S$. cerevisiae and found no effect on digestibility of OM, ADF or NDF in dairy cows, but there was a tendency for lower apparent $\mathrm{CP}$ digestibility in steers, and no effect on apparent $\mathrm{OM}$ and $\mathrm{CP}$ digestibility in dairy cows (Chiquette 1995). As there is no reason to believe that true digestibility of OM and CP would decrease due to YST feeding, since the basal diets were all the same and since aNDFom and starch digestion was not impaired, it is likely that the decreased apparent $\mathrm{OM}$ and $\mathrm{CP}$ 
digestion was because more $\mathrm{OM}$ and $\mathrm{CP}$ entered the small intestine in endogenous secretions. This suggests that intestinal health might have been improved due to feeding YST, which could have led to increased true digestion, which is supported by the higher plasma AA levels of cows fed the YST diet.

Effects of DFM products on intestinal health have been studied extensively in nonruminant animals, especially effects on GI health in poultry. However little research has been completed on effects of DFM products on post ruminal GI health in ruminants. ChaucheyrasDurand et al., (2012) stated that yeast probiotics passing through the rumen might affect intestinal homeostasis thereby influencing the animal health and affecting the immune system. Increased plasma AA levels in the YST cows, and the increased milk production in the YST cows, might suggest that an increase in post ruminal absorption efficiency caused the higher plasma AA levels which drove higher milk yield. Indeed one would expect to see a decrease in the AA concentrations in the blood plasma as milk yields increase, such as in the case of the XPC treatment and as commonly observed in literature (Trottier, 1997; Xu et al., 1998) but, as the opposite occurred with our YST treatment, these higher plasma AA levels in the YST cows suggest an increase in intestinal AA absorption efficiency.

Live yeasts are naturally found in the rumen, but normal rumen temperature does not promote their growth since optimal yeast growth occurs at about $25^{\circ} \mathrm{C}$ (Lund, 1974), and live yeast has very little ability to remain viable in the rumen for more than $24 \mathrm{~h}$, thus having a limited ability to multiply (Kung et al., 1997). Gut micro-flora have important effects on host animal health, nutrition and performance by affecting utilization of nutrients and development of the GI system of the host (Barrow, 1992). This interaction is complex and, depending on the activity and composition of the gut micro-flora, it can have either negative or positive effects on animal health (Giannenas et al., 2012). Probiotic products influence the intestinal microbial system of monogastric animals in multiple ways (Ng et al., 2009). 
The microbial population in the GI tract of mammals can be considered to be a metabolically active organ with wide biodiversity in terms of species and a high number of cells (Gaggia et al., 2010). A normal bacterial biome in the rumen and post ruminal GI tract is an important health asset with a nutritional purpose and a protective impact on intestinal structure and homeostasis (Gaggia et al., 2010). In the GI tract of mammals the mucosal barrier separates the internal environment from the luminal environment (Gaggia et al., 2010) and the mucus layer is formed by interaction of numerous mucosal secretions such as mucin glycoproteins, surfactant phospholipids and trefoil peptides (Guarner and Malagelada 2003). The intestinal epithelium and mucus provide the first physical line of defense that mediates active resident bacteria, pathogens, antigens and immune cells (Gaggia et al., 2010). Resident bacteria may exert a dual purpose by stimulation of mucosal mechanism defense while having an effect on maintenance of homeostasis of the immune response (Gaggia et al., 2010). Stressors that lead to malfunction of the intestinal barrier, and an increase in intestinal permeability, may have a negative impact on gut microbial composition and increase susceptibility to enteric pathogens (Gareau et al., 2009). An example of animals exposed to such a stressor are high producing dairy cows; especially those in early lactation induced in a negative energy balance.

Lee et al. (2009), Giannenas et al. (2012) and Salim et al. (2013) demonstrated altered intestinal morphometric measurements when B. subtilis bacterial strains were fed to broilers, and showed an increase in villus height and crypt depth in the small intestine. This might occur in the rumen of mature cows, as well as in the post ruminal GI tract, leading to increased villus height and width thereby increasing surface area available for absorption leading to increased nutrient absorption. This might also explain the decreased apparent digestibility of $\mathrm{OM}$ and $\mathrm{CP}$ in our study. For example an increase in post ruminal health and an increased surface area available for absorption means that there was also increased surface 
area for attachment of microbes to the gut wall and thus a larger microbial biome and, due to potentially increased GI health, endogenous secretion levels would be higher, and so this increased gut health would lead to an increase in nutrient absorption and production, as occured with YST in our study.

Yeasture increased, in general, the AA concentrations in the blood plasma of cows. This might be due to an increase in AA in the digesta (less possible as previously discussed) and/or increased nutrient absorption (more possible as discussed). Indeed many EAA levels increased with YST, as did some NEAA. The AA that did increase might also support an increase in GI tract health in the YST group, as these AA were threonine, tryptophan, glycine and asparagine, all of which have been associated with enhanced immune response (Li et al. 2007)

\subsection{Effects of XPC supplementation}

Only one published study utilizing XPC makes direct comparison of our results to those of others difficult since the general literature of DFM yeast products is virtually exclusively product based. Nevertheless our animal production results are consistent with Li et al. (2016) in which addition of XPC at $14 \mathrm{~g} / \mathrm{cow} / \mathrm{d}$ had no impact on milk production or milk component levels. However our results can be compared to Diamond V Mills 'XP' as there are several research publications available on effects of XP on dairy cow production, and both products are S. cerevisiae yeast culture based products. The difference between XPC and $\mathrm{XP}$, as stated by the manufacturer, is that $\mathrm{XPC}$ is a concentrated low inclusion form of $\mathrm{XP}$ (i.e., 4 times higher dietary inclusion rate for XP versus XPC). According to Poppy et al. (2012), XP and XPC are equivalent products except for concentrations of some active metabolites. Erasmus et al. (2005) reported a small numerical increase in milk yield by feeding XP, but no difference in milk composition except for increased milk $\mathrm{CP}$ concentrations. Robinson and Garrett (1999) also found no effect of XP on milk production 
in spite of a small numerical increase. Robinson (1997) also found no effect on milk production when XP was fed. However when Robinson and Erasmus (2008) summarized results of $7 \mathrm{XP}$ lactation studies they reported increases in milk (3.6\%), milk fat (4.9\%) and CP $(2.4 \%)$ yields, as well as $3 \%$ higher daily milk energy output, and this is in general agreement with a meta-analysis by Poppy et al. (2012). The overall lack of a performance response increase of the XPC supplemented cows in our study, consistent with Li et al. (2016), shows that it is not equivalent to XP where benefits have been reported (Robinson

and Erasmus, 2008), at least at the feeding level which we used. Zaworski et al. (2014) reported a decrease in the SCC of cows fed XP, which also contrasts to our study were no effect of XPC supplementation on SCC occurred.

Ingvartsen and Moyes (2013) proposed that improved nutrient and energy utilization, as well as increased absorption of nutrients in cows fed yeast cultures may increase the innate immune response and play a role in improving animal production, but this did not appear to occur with XPC in our study. That the plasma EAA concentrations were slightly lower does not support increased absorption efficiency, as was the case with YST.

\section{Conclusions}

Our results provide no evidence to suggest that there was a ruminal effect with either DFM yeast product because the apparent total tract fiber digestion and microbial CP flow were not affected by either. However, results show an increased energetic output with both DFM products, suggesting an increase in efficiency of nutrient use, but that the mechanisms by which production was influenced differed between products; with the YST DFM primarily affecting NE output due to a potential increase in post ruminal GI tract health leading to an increase in post ruminal nutrient absorption while XPC may have had a small increase in microbial CP flow due to improved coupling of protein and energy utilization in the rumen. 
Results provide a basis for future studies to investigate DFM yeast products, especially relative to their post ruminal GIT affects. We propose that when the yeast based DFM YST was supplemented a possible post ruminal response occurred to improve gut health in the small intestine thereby leading to increased nutrient absorption efficiency.

\section{Acknowledgements}

The authors would like to thank Mr. William van Die and the team on the farm for their help, cooperation, patience and interest during the study. The first author would also like to thank Grace Cun, Jill Havlin, Kara Ortega, Katie Olagary, Kristan Reed and Nadia Swanepoel with all their help to collect samples and for their continuous support.

\section{References}

AOAC Official Method 2003.05, 2006. Crude fat in feeds, cereals, grains and forages. In:

Official Methods of Analysis of AOAC International, 18th edition, chapter 4 pp. 40-42, AOAC International, Arlington, VA, USA.

AOAC Official Method 973.18, 1997. Fiber (acid detergent) and lignin in animal feed. In:

Official Methods of Analysis of AOAC International, 16th edition, chapter 4 pp. 28-29, AOAC International, Arlington, VA, USA.

AOAC Official Method 990.03, 2005. Protein (crude) in animal feed, combustion method. In:

Official Methods of Analysis of AOAC International, 18th edition, chapter 4 pp. 30-31, AOAC International, Arlington, VA, USA.

Barrow, P., 1992. Probiotics for chickens. In: Fuller, R. (Ed.), Probiotics the scientific basis. Chapman and Hall, London, UK, 225-257.

Barton, M.D., 2000. Antibiotic use in animal feed and its impact on human health. Nutr. Res. Rev. 13, 279-299. 
Bitencourt, L.L., Silva, J.R.M., de Oliveira, B.M.L., Dias G.S., Jnr., Lopes, F., Siécola, S. Jnr., Zacaroni, O., Pereira, M.N., 2011. Diet digestibility and performance of dairy cows supplemented with live yeast. Sci. Agric. 68, 301-307.

Blümmel, M., Ørskov, E.R., 1993. Comparison of in vitro gas production and nylon bag degradability of roughages in predicting feed intake in cattle. Anim. Feed Sci. Tech. 40, $109-119$.

Burgos, S.A., Robinson, P.H., Fadel, J.G., DePeters, E.J., 2005. Ammonia volatilization potential: Prediction of urinary urea nitrogen output in lactating dairy cows. Agri. Ecosystems and Environ. 111, 261-269.

Chaucheyras-Durand, F., Chevaux, E., Martin, C., Forano, E., 2012. Use of Yeast Probiotics in Ruminants: Effects and Mechanisms of Action on Rumen pH, Fibre Degradation, and Microbiota According to the Diet, Probiotic in Animals, Prof. Everlon Rigobelo (Ed.), ISBN: 978-953-51-0777-4, InTech, DOI: 10.5772/50192.

Chen, X.B., Gomes, M.J., 1992. Estimation of microbial protein supply to sheep and cattle based on urinary excretion of purine derivatives - An overview of the technical details. Int. Feed Res. Unit, Occasional Publ. Rowett Research Institute, Aberdeen, UK.

Chilliard, Y., Cissé, M., Lefaivre, R., Rémond, B., 1991. Body composition of dairy cows according to lactation stage, somatotropin treatment, and concentrate supplementation. J. Dairy Sci. 74, 3103-3116.

Chiquette, J., 1995. Saccharomyces cerevisiae and Aspergillus oryzae, used alone or in combination, as a feed supplement for beef and dairy cattle. Can. J. Anim. Sci. 75, 405415.

Dawson, K.A., Newman, K.E., Boling, J.A., 1990. Effects of microbial supplements containing yeast and lactobacilli on roughage fed ruminal microbial activities. J. Anim. Sci. $68,3392-3398$. 
Desnoyers, M., Giger-Reverdin, S., Bertin, G., Duvaux-Ponter, C., Sauvant, D., 2009. Metaanalysis of the influence of Saccharomyces cerevisiae supplementation on ruminal parameters and milk production of ruminants. J. Dairy Sci. 92, 1620-1632.

DiLorenzo, N., 2010. Manipulation of the rumen microbial environment to improve performance of beef cattle. North Florida Research and Education Center, University of Florida, Gainesville, FL, USA.

Erasmus, L.J., Botha, P.M., Kistner, A., 1992. Effect of yeast culture supplement on production, rumen fermentation and duodenal nitrogen flow in dairy cows. J. Dairy Sci. $75,3056-3065$.

Ferguson, J.D., Galligan, D.T., Thomsen, N., 1994. Principal descriptors of body condition score in Holstein cows. J. Dairy Sci. 77, 2695-2703.

Gaggìa, F., Mattarelli, P., Biavati, B., 2010. Probiotics and prebiotics in animal feeding for safe food production. Int. J. Food Microb. 141, 15-28.

Gareau, M.G., Wine, E., Sherman, P.M., 2009. Early life stress induces both acute and chronic colonic barrier dysfunction. NeoReviews 10, 191-197.

Giannenas, I., Papadopoulos, E., Tsalie, E., Triantafilloud, El., Henikle, S., Teichmanne, K., Tontisc, D., 2012. Assessment of dietary supplementation with probiotics on performance, intestinal morphology and microflora of chickens infected with Eimeria tenella. Vet. Parasitology 188, 31-40.

Groot, J.C.J., Cone, J.W., Williams, B.A., Debersaques, F.M.A., Lantinga, E.A., 1996. Multiphasic analysis of gas production kinetics for in vitro fermentation of ruminant feeds. Anim. Feed Sci. Tech. 64, 77-89.

Guarner, F., Malagelada, J.R., 2003. Gut flora in health and disease. The Lancet 361, 512519. 
Higginbotham, G., Robinson, P.H., Shultz, T., Spicer, L., Sullivan, J., 1999. Effect of BioYeast on milk yield and related responses in a commercial California dairy herd. University of California, Cooperative Extension. Davis, CA, USA.

Ingvartsen, K.L., Moyes, K., 2013. Nutrition, immune function and health of dairy cattle. Animal. 7, 112-122.

Johansen, H.N., Glitsø, V., Knudsen, K.E.B., 1996. Influence of extraction solvent and temperature on the quantitative determination of oligosaccharides from plant materials by high-performance liquid chromatography. J. Agric. Food Chem. 44, 1470-1474.

Johnson, C.M., Ulrich, A., 1959. Analytical methods for use in plant analysis. Bulletin 766. University of California, Agricultural Experiment Station, Berkeley, CA, USA.

Krishnamoorthy, U., Muscato, T., Sniffen, C.J., Van Soest, P.J., 1982. Nitrogen fractions in selected feedstuffs. J. Dairy Sci. 65, 217-225.

Kristensen, N.B., Duchwaider, V., Røjen, B.A., 2014. Effects of dietary yeast supplementation on milk production, feed intake, fecal, and urinary variables in dairy cows under field conditions in Denmark. Knowledge Centre for Agriculture, Cattle, Agro food park 15, DK-8200 Aarhus N, Denmark.

Kung Jr., L., Kreck, E.M., Tung, R.S., Hession, A.O., Sheperd, A.C., Cohen, M.A., Swain, H.E., Leedle, J.A., 1997. Effects of a live yeast culture and enzymes on in vitro ruminal fermentation and milk production of dairy cows. J. Dairy Sci. 80, 2045-2051.

Lee, K.W., Lee, S.H., Lillehoj, H.S., Li, G.X., Jang, S.I., Babu, U.S., Park, M.S., Kim, D.K., Lillehoj, E.P., Neumann, A.P., Rehberger, T.G., Siragusa, G.R., 2009. Effects of directfed microbials on growth performance, gut morphometry, and immune characteristics in broiler chickens. J. Poult. Sci. 89, 203-216.

Li, S., Yoon, I., Scott, M., Khafipour, E., Plaizier, J.C., 2016. Impact of Saccharomyces cerevisiae fermentation product and subacute ruminal acidosis on production, 
inflammation, and fermentation in the rumen and hindgut of dairy cows. Anim. Feed Sci. Technol. 211, 50-60.

Li, P., Yin, Y.L., Li, D., Kim, S.W., Wu, G., 2007. Amino acids and immune function. Dept. Animal Science, Texas A\& M University, College Station, TX, USA.

Lila, Z.A., Mohammed, N., Yasui, T., Kurokawa, Y., Kanda S., Itabashi, H., 2004. Effects of a twin strain of Saccharomyces cerevisiae live cells on mixed ruminal microorganism fermentation in vitro. J. Anim. 82, 1847-1854.

Lund, A., 1974. Yeast and moulds in the bovine rumen. J. of Gen. Microb. 81, 453-462.

Menke, K.H., Steingass, H., 1988. Estimation of the energetic feed value obtained from chemical analysis and gas production using rumen fluid. Anim. Res. Dev. 28, 7-55.

Meyer, G.A., Keliher, P.N., 1992. An overview of analysis by inductively coupled plasmaatomic emission spectrometry. p. 473-516. In: A. Montaser and D.W. Golightly (ed.) Inductively coupled plasmas in analytical atomic spectrometry. VCH Publishers Inc. New York, NY, USA.

National Research Council, 2001. Nutrient Requirements of Dairy Cattle, 7th revised edition. National Academy Press, Washington, DC, USA.

NFTA, 2001. Laboratory dry matter by oven drying for 3 hours at $105^{\circ}$. moisture task force report, 2.2.2.5. National Forage Testing Association, Omaha, NE, USA.

Ng, S.C., Hart, A.L., Kamm, M.A., Stagg, A.J., Knight, S.C., 2009. Mechanisms of action of probiotics: Recent advances. Inflamm. Bowel Dis. 15, 300-310.

Patra, A.K., 2011. Effects of essential oils on rumen fermentation, microbial ecology and ruminant production. Asian J. Anim. Vet. Adv. 6, 416-428.

Poppy, G.D., Rabiee, A.R., Lean, I.J., Sanchez, W.K., Dorton, K.L., Morley, P.S., 2012. A meta-analysis of the effects of feeding yeast culture produced by anaerobic fermentation 
of Saccharomyces cerevisiae on milk production of lactating dairy cows. J. Dairy Sci. 95, $6027-6041$

Purser, D.B., Buechler, S.M., 1966. Amino acid composition of rumen organisms. J. Dairy Sci. 49,81 .

Rauch, R.E., Robinson, P.H., Erasmus, L.J., 2012. Effects of sodium bicarbonate and calcium magnesium carbonate supplementation on performance of high producing dairy cows Anim. Feed Sci. Tech. 177, 180-193.

Robinson, P.H., 1997. Effect of yeast culture (Saccharomyces cerevisiae) on adaptation of cows to diets postpartum. J. Dairy Sci. 80, 1119-1125.

Robinson, P.H., 2013. Yeast products for lactating and growing ruminants: A literature summary of impacts on rumen fermentation and performance. University of California. Cooperative Extension. Davis, CA, USA.

Robinson, P.H., Erasmus, L.J., 2008. Effects of analysable diet components on responses of lactating dairy cows to Saccharomyces cerevisiae based yeast products: A systematic review of the literature. Anim. Feed Sci. Tech. 149, 185-198.

Robinson, P.H., Garrett, J.E., 1999. Effect of yeast culture (Saccharomyces cerevisiae) on adaptation of cows to postpartum diets and on lactational performance. J. Anim. Sci. 77, 988-999.

Robinson, P.H., Givens, D.I., Getachew, G., 2004. Evaluation of NRC, UC Davis and ADAS approaches to estimate the metabolizable energy values of feeds at maintenance energy intake from equations utilizing chemical assays and in vitro determinations. Anim. Feed Sci. Tech. 114, 75-90.

Robinson, P.H., Meyer, D., 2010. Total Mixed Ration Sampling Protocol. University of California Agricultural and Natural Resources, Oakland, CA, USA. 
Russell, J.B. 2002. Rumen microbiology and its role in ruminant nutrition. Russell Publications, Ithaca, NY, USA.

Salim, H.M., Kang, H.K., Akter, N., Kim, D.W., Kim, J.H., Kim, M.J., Na, J.C., Jong, H.B., Choi, H.C., Suh, O.S., Kim, W.K., 2013. Supplementation of direct-fed microbials as an alternative to antibiotic on growth performance, immune response, cecal microbial population, and ileal morphology of broiler chickens. Poultry Sci. 92, 2084-2090.

SAS Institute Inc., 2000. SAS/STAR®Software: Changes and Enhancements, Release 9.2. SAS Institute Inc., Cary, NC, USA.

Soder, K.J., Holden, L.A., 1999. Dry matter intake and milk yield and composition of cows fed yeast prepartum and postpartum. J. Dairy Sci. 82, 605-610.

Steel, R.G.D., Torrie, J.H., 1960. Principles and Procedures of Statistics. McGraw-Hill Book Co., New York, NY, USA.

Stensig, T., Robinson, P.H., 1997. Digestion and passage kinetics of forage fiber in dairy cows as affected by fiber-free concentrate in the diet. J. Dairy Sci. 80, 1339-1352.

Stretenović, Lj., Petrović, M.P., Aleksić, S., Pantelić, V., Katić, V., Bogdanović, V., Beskorovajni, R., 2008. Influence of yeast, probiotics and enzymes in rations on dairy cows performances during transition. Biotec. Anim. Husb. 24, 33-43.

Swanepoel, N., Robinson, P.H., Erasmus L.J., 2010. Amino acid needs of lactating dairy cows: Predicting limiting amino acids in contemporary rations fed to high producing dairy cattle in California using metabolic models. Anim. Feed Sci. Tech. 161, 103-120.

Swanepoel, N., Robinson, P.H., Erasmus, L.J., 2014. Determining the optimal ratio of canola meal and high protein dried distillers grain protein in diets of high producing Holstein dairy cows. Anim. Feed Sci. Tech. 189, 41-53. 
Tracy, M.L., Moeller, G., 1990. Continuous flow vapor generation for inductively coupled argon plasma spectrometric analysis. Part 1: selenium. J. Assoc. Off. Anal. Chem. 73, 404-410.

Trottier, N.L., 1997. Nutritional control of amino acid supply to the mammary gland during lactation in the pig. Proc. Nutr. Soc. 56, 581-591.

Tyrrell, H.F., Reid, J.T., 1965. Prediction of the energy value of cow's milk. J. Dairy Sci. 48, $1215-1223$.

Van Soest, P.J., 1994. Nutritional ecology of the ruminant. Cornell University: Cornell University Press.

Van Soest, P.J., Robertson, J.B., Lewis, B.A., 1991. Methods for dietary fibre, neutral detergent fibre, and non-starch polysaccharides in relation to animal nutrition. J. Dairy Sci. 74, 3583-3591.

Wildman, E.E., Jones, G.M., Wagner, P.E., Boman, R.L., 1982. A dairy cow conditioning system and its relationship to selected production characteristics. J. Dairy Sci. 65, 495501.

Williams, P.E.V., Newbold, J.C., 1990. Rumen probiosis: The effects of novel microorganisms on rumen fermentation and rumen productivity. In Recent Advances in Animal Nutrition (W. Haresign and D.J.A. Cole, eds.). Butterworths, London, UK.

Xu, S., Harrison, J.H., Chalupa, W., Sniffen, C., Julien, W., Sato, H., Fujieda, T., Watanabe, K., Ueda, T., Suzuki, H., 1998. The effect of ruminal bypass lysine and methionine on milk yield and composition of lactating cows. J. Dairy Sci. 81, 1062-1077.

Zaworski, E.M., Shriver-Munsch, C.M., Fadden, N.A., Sanchez, W.K., Yoon, I., Bobe, G., 2014. Effects of feeding various dosages of Saccharomyces cerevisiae fermentation product in transition dairy cows. J. Dairy Sci. 97, 3081-3098. 